\title{
An Explorative Study on Sales Distribution in M-commerce
}

\author{
Yongjin Park \\ KAIST College of Business \\ livediary@business.kaist.ac.kr
}

\author{
Youngsok Bang \\ CUHK Business School \\ bangyoungsok@baf.cuhk.edu.hk
}

\author{
Jae-Hyeon Ahn \\ KAIST College of Business \\ jahn@business.kaist.ac.kr
}

\begin{abstract}
Despite the proliferation of studies on the sales distribution in e-commerce, little research has been conducted on the sales distribution in the m-commerce channel. This study empirically examines the sales distribution of various product categories in the mobile channel, using the large transaction data from a leading e-marketplace in Korea. Overall, transactions in the mobile channel are more concentrated to head products compared to the PC channel sales, but the pattern is inconsistent across product categories. Transactions in product categories of high average price (e.g., computers) and low purchase frequency rate (e.g., health care products) are less concentrated to head products in the mobile channel than the PC channel. The revenue distribution, however, shows the opposite. Head products generate relatively less revenue in the mobile channel than the PC channel. We provide explanations why the mixing results appear across product categories and between the distribution types.
\end{abstract}

\section{Introduction}

The demand curve of the online market is characterized by the "long tail" where hard-to-find products in traditional retail markets have higher shares and generate substantial profits [1]. Without binding constraints on product storage and display space, online markets carry more products and provide more options to buy for consumers. Consumers discover niche products that better suit their needs using powerful search tools available in online markets. Online retailers get a selection advantage over brickand-mortar retailers and significantly enhance the consumer surplus with their product variety [5][6].

As the demand shift towards niche products in online markets casts significant meanings in digital economy with online retailers' different revenue structure and increased consumer surplus, many researchers empirically investigated the long tail phenomenon in various markets including book [5][20], clothing [4], music [8], and video [9] and DVD
[16][23]. However, prior research on the demand curve in online markets is more or less limited to the comparison of sales distribution between the brickand-mortar channel and traditional online channel or between two online channels where the mobile channel was not available. Little is known about how the demand curve is shaped in the presence of mobile channels, which have become popular purchase channels but have unique properties differentiated from the traditional PC channel.

Internet-enabled mobile devices such as smartphones allow consumers to access online markets and search for products anytime and anywhere. On one hand, ubiquitous access and search possibilities afforded by mobile channels release the transportation cost of finding a fixed place that has the Internet connection and a PC for online shopping, which could promote more searches in online markets. For example, a consumer could continue product search by hopping from the PC to the smartphone when s/he needs to go outside. This would reshape the demand curve in online market by fattening the tail. On the other hand, small screens and limited usability of mobile devices put constraints on extensive product search in online markets and could entice consumers to featured products, resulting in fattening the head. Considering both possibilities, the impact of mobile channels on demand curve remains the empirical question.

Further, as most prior studies focus on the demand curve of a single product category, there is little guidance how the sales distribution in the mobile channel would differ across product categories. The results of previous studies report largely different degrees of online sales dispersion across product categories. The Gini coefficient of the sales distribution of online markets reports ranging from 0.35 to 0.93 depending on the product category (Table 1). 
Table 1. Gini coefficients in prior research

\begin{tabular}{cll}
\hline Paper & \multicolumn{1}{c}{ Context } & \multicolumn{1}{c}{ Measure } \\
\hline$[22]$ & Movie ratings in & $0.8067,0.8315,0.8193,0.8155,0.8339$, \\
& Netflix & 0.8491 (from 2000 to 2005) \\
\hline$[4]$ & Women's & 0.49 (Internet), 0.53 (catalog) \\
& clothing & \\
\hline$[13]$ & VOD sales in & 0.637 (mean for 111 weak from March \\
& Germany & $2005)$ \\
& & 0.553 (min), 0.732 (max) \\
{$[18]$} & Amazon book & 0.73 (overall mean) \\
& sales & 0.76 (science book) \\
& & 0.51 (computer and Internet) \\
\hline$[25]$ & Total downloads & 0.93 (paid app) \\
& on the Google & 0.88 (free app) \\
& Play app market & \\
\hline$[14]$ & Mobile App & 0.74 (overall mean) \\
& usage from & 0.83 (communications), 0.79 (social \\
& Android users in & media), 0.74 (entertainment), 0.64 \\
& Korea & (news), 0.35 (game) \\
\hline$[16]$ & Movie DVD & 0.67 (before the broadcast on TV) \\
& sales in U.S. & 0.59 (after the broadcast on TV) \\
\hline$[23]$ & Movie DVD & 0.806 (January 2001) \\
& rental in U.S. & 0.843 (July 2005) \\
\hline [19] & Internet news & $0.816,0.762$ (NYT articles in the pre- \\
& & and the post-paywall period) \\
& & $0.653,0.630$ (LAT articles before and \\
& & after NYT's paywall rollout) \\
\hline & &
\end{tabular}

We aim to expand this stream of research by investigating the sales distribution in the mobile channel across multiple product categories. Using the large-scale data from a leading e-marketplace in Korea, we empirically compare the demand shapes between the PC and mobile channels across different product categories.

Overall, transactions in the mobile channel are more concentrated to head products compared to the PC channel sales, but the pattern is inconsistent across product categories. Transactions in product categories of high average price (e.g., computer, audio/video supply) and low purchase frequency rate (e.g., health care products) are less concentrated to head products in the mobile channel than the PC channel. The revenue distribution, however, shows the opposite. Based on the analysis results, we provide explanations why those product categories have a longer (or shorter) sales tail in the mobile channel than in the traditional PC channel. We also conduct several robustness check analyses to support and confirm our explanations.

The rest of the paper is organized as follows. We first examine the sales distribution of various product categories in the mobile channel and compare it with the sales distribution of the corresponding product categories in the PC channel. Subsequently, we provide explanations why the mobile channel possesses a longer (or shorter) tail distribution than the PC channel in some product categories. Lastly, we conclude with a discussion on our empirical findings and managerial implications of the study.

\section{Comparison of sales distribution between the PC and mobile channels}

\subsection{Data}

We use a large transaction dataset from the database of a leading e-marketplace in Korea that had initially provided the PC channel only and launched the mobile channel later. The dataset contains a random sample of 60,000 users and their entire transactions during two years (from June 2009 to May 2011). The e-marketplace launched its mobile channel on June 1st, 2010, and our data period covers one year before and after the mobile channel introduction by the e-marketplace.

To clearly compare the sales distribution between the PC and mobile channels, we exclude 27,238 users from the initial dataset who signed-up the emarketplace during our observation period. The incoming of new users could distort the tail length, as their joining might be associated with the intention to purchase products at the time of signing-up [13]. Our main sample contains 32,762 users and their over 1.5 million transaction records including 45,477 transactions conducted through the mobile channel (Table 2). Among 37 product categories in the emarketplace, "women's clothing" category has the largest number of transactions both in the PC and mobile channels. The mobile channel transaction accounts for $4.7 \%$ of the whole transactions.

Table 2. PC and mobile channel transactions

\begin{tabular}{ccc}
\hline Channel & June 2009 May 2010 & June 2010 May 2011 \\
\hline PC & 677,995 & $915,780(95.269 \%)$ \\
Mobile & - & $45,477(4.731 \%)$ \\
\hline
\end{tabular}

\subsection{Sales distribution in the mobile channel}

The mobile channel adopters and non-adopters might be heterogeneous regarding demographic composition or purchasing habits, which could be the cause of different shapes of the sales distribution between the PC and mobile channels. For example, mobile channel adopters might be younger and more innovative than non-adopters. To tease out the pure channel effect on the sales distribution, we first employ the propensity score matching (PSM) to match orders in the PC and mobile channels [4]. We use users' demographic variables (gender, age) and their order summary measures (recency, frequency, and monetary value) before the mobile channel introduction by the emarketplace to generate the propensity score of each order. Studies in the direct marketing literature show 
that recency, frequency, and monetary value are sufficient statistics to summarize purchase histories of each customer, which provide theoretical justification for the use of these measures [10].

The PC and mobile samples are matched well as none of demographic variables and order summary measures are significantly different after matching (Table 3), which addresses the potential selection bias issue in comparing the sales distribution between channels [4].

Table 3. Propensity score matching results

\begin{tabular}{|c|c|c|c|c|c|}
\hline $\begin{array}{l}\text { Matching } \\
\text { variables }\end{array}$ & $\begin{array}{l}\text { Mobile } \\
\text { sample }\end{array}$ & $\begin{array}{c}\mathrm{PC} \\
\text { sample }\end{array}$ & Difference & $\begin{array}{l}\text { Matched } \\
\text { PC } \\
\text { sample } \\
\text { (probit) }\end{array}$ & $\begin{array}{c}\text { Matched } \\
\text { PC } \\
\text { sample } \\
\text { (logit) }\end{array}$ \\
\hline Male Ratio & 0.358 & 0.350 & $\begin{array}{c}0.008^{\star \star \star} \\
(0.002)\end{array}$ & $\begin{array}{c}0.357 \\
(0.003)\end{array}$ & $\begin{array}{c}0.355 \\
(0.003)\end{array}$ \\
\hline Age & 30.034 & 31.790 & $\begin{array}{l}1.756^{\star \star \star} \\
(0.037)\end{array}$ & $\begin{array}{l}30.005 \\
(0.047)\end{array}$ & $\begin{array}{l}29.990 \\
(0.047)\end{array}$ \\
\hline Recency & 3.307 & 3.803 & $\begin{array}{c}0.496 * \star * \\
(0.006)\end{array}$ & $\begin{array}{c}3.309 \\
(0.010)\end{array}$ & $\begin{array}{c}3.310 \\
(0.010)\end{array}$ \\
\hline Frequency & 3.365 & 3.921 & $\begin{array}{c}0.556 \text { *** } \\
(0.006)\end{array}$ & $\begin{array}{c}3.368 \\
(0.010)\end{array}$ & $\begin{array}{c}3.369 \\
(0.010)\end{array}$ \\
\hline Monetary & 3.325 & 3.848 & $\begin{array}{c}0.523^{\star * * *} \\
(0.006)\end{array}$ & $\begin{array}{c}3.327 \\
(0.010)\end{array}$ & $\begin{array}{c}3.327 \\
(0.010)\end{array}$ \\
\hline $\begin{array}{l}\text { Sample } \\
\text { size }\end{array}$ & 38,626 & 862,371 & & 38,626 & 38,626 \\
\hline
\end{tabular}

Note: Standard errors are in parentheses.

Then, we generate the Lorenz curve and calculate the Gini coefficient of the sales distribution in the PC and mobile channels to compare the demand shape between the two channels. Lorenz curve depicts the sales proportion of the bottom $\mathrm{x} \%$ of products. Higher Lorenz curve (closer to the $45^{\circ}$ equality line) represents the longer tail of the sales distribution. The Gini coefficient measures the ratio of the area in between $45^{\circ}$ equality line and the Lorenz curve to the area under the equality line. A greater Gini coefficient represents more concentration of sales on head products.

When we sort products by demand, the Lorenz curve of the mobile channel locates below the curve of the PC channel, meaning more niche products were sold in the PC channel than the mobile channel (Figure 1). The Gini coefficient of the sales distribution in the mobile channel (0.494) is also higher than the PC channel (0.438), confirming that the PC channel has the longer tail than the mobile channel.

However, when we sort products by revenue, the results are opposite. The Lorenz curve of the mobile channel locates above the curve of the PC channel, showing more revenue was generated from head products in the PC channel (Figure 2). The Gini coefficient of the sales distribution in the mobile channel (0.594) is also lower than the coefficient in the PC channel (0.696).

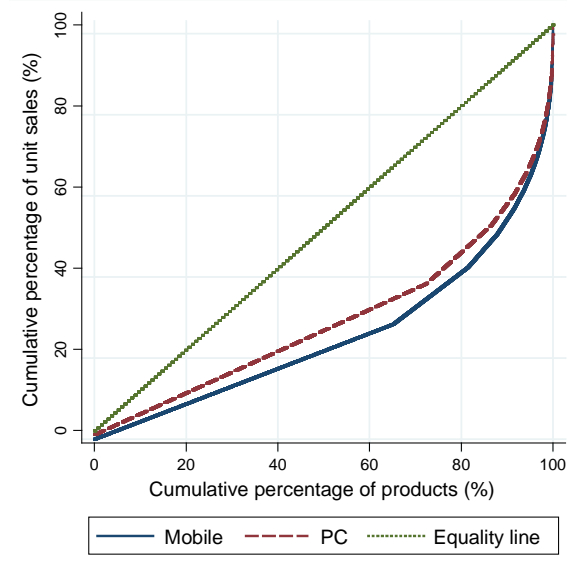

Figure 1. Lorenz curve of demand

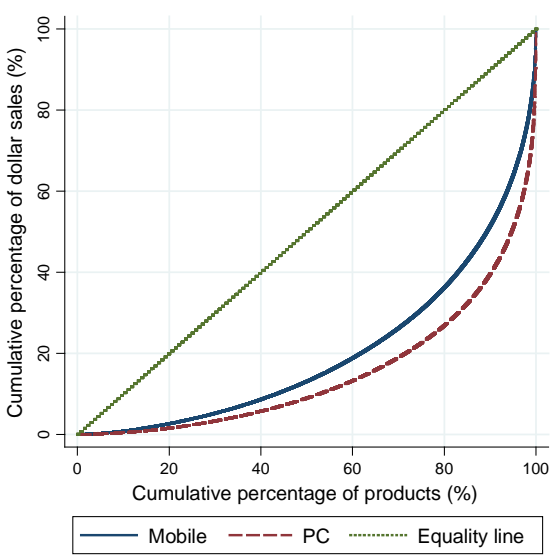

Figure 2. Lorenz curve of revenue

For more rigorous analysis, we examine the loglinear relationship between sales and sales rank of product $j$ [4][5] (Eq 1). Lower rank means higher sales. The $\beta_{1}$ estimated from the sales distribution of the mobile channel would have greater (smaller) absolute value than the PC channel if it is more (less) negatively skewed. To statistically test the difference in size of $\beta_{1}$ between the two channels, we incorporate the dummy for mobile transactions (Mobile) and run a simple regression to check the significance of $\beta_{3}$ after pooling the PC and mobile samples (Eq 2).

$\ln \left(\right.$ Sales $\left._{j}\right)=\beta_{0}+\beta_{1} \ln \left(\right.$ Sales Rank $\left._{j}\right)+\varepsilon_{j} \quad($ Eq 1$)$ $\ln \left(\right.$ Sales $\left._{j}\right)=\beta_{0}+\beta_{1} \ln \left(\right.$ Sales Rank $\left._{j}\right)+\beta_{2}$ Mobile $_{j}$ $+\beta_{3}$ Mobile $_{j} \times \ln \left(\right.$ Sales Rank $\left._{j}\right)+\varepsilon_{j}$ 
Table 4. Log-linear relationship between sales and sales rank (demand)

\begin{tabular}{|c|c|c|c|c|}
\hline $\begin{array}{l}\text { DV: } \\
\text { In(Demand) }\end{array}$ & $\begin{array}{c}(1) \\
\text { Mobile }\end{array}$ & $\begin{array}{l}\text { (2) } \\
\text { PC }\end{array}$ & $\begin{array}{c}\text { (3) } \\
\text { Pooled data, } \\
\text { linear regression }\end{array}$ & $\begin{array}{c}\text { (4) } \\
\text { Pooled data, } \\
\text { quantile regression }\end{array}$ \\
\hline In(Sales Rank) & $\begin{array}{c}-0.713^{\star \star *} \\
(0.001)\end{array}$ & $\begin{array}{c}-0.635^{\star \star \star} \\
(0.000)\end{array}$ & $\begin{array}{c}-0.635^{\star \star \star} \\
(0.000)\end{array}$ & $\begin{array}{c}-0.625^{\star * *} \\
(0.000)\end{array}$ \\
\hline Mobile & & & $\begin{array}{c}0.668^{\star \star \star} \\
(0.009)\end{array}$ & $\begin{array}{c}1.027^{\star \star \star} \\
(0.001)\end{array}$ \\
\hline $\begin{array}{l}\text { Mobile x } \\
\text { In(Sales Rank) }\end{array}$ & & & $\begin{array}{c}-0.078^{\star * *} \\
(0.001)\end{array}$ & $\begin{array}{c}-0.117^{\star \star \star *} \\
(0.000)\end{array}$ \\
\hline Constant & $\begin{array}{c}6.835^{\star \star *} \\
(0.008)\end{array}$ & $\begin{array}{c}6.167^{\star \star \star *} \\
(0.003)\end{array}$ & $\begin{array}{c}6.167^{* * *} \\
(0.003)\end{array}$ & $\begin{array}{c}6.073^{\star * *} \\
(0.001)\end{array}$ \\
\hline Adjusted $R^{2}$ & 0.998 & 0.999 & 0.999 & 0.980 \\
\hline Sample size & 21,156 & 25,942 & 47,098 & 47,098 \\
\hline
\end{tabular}

Note: Robust standard errors are in model (1) (3) parentheses.

Standard errors and pseudo $R^{2}$ in model (4). ${ }^{* \star *} p<0.01$.

Table 5. Log-linear relationship between sales and sales rank (revenue)

\begin{tabular}{|c|c|c|c|c|}
\hline $\begin{array}{l}\text { DV: } \\
\text { In(Revenue) }\end{array}$ & $\begin{array}{c}(1) \\
\text { Mobile }\end{array}$ & $\begin{array}{l}\text { (2) } \\
\text { PC }\end{array}$ & $\begin{array}{c}(3) \\
\text { Pooled data, } \\
\text { linear regression }\end{array}$ & $\begin{array}{c}(4) \\
\text { Pooled data, } \\
\text { quantile } \\
\text { regression }\end{array}$ \\
\hline In(Sales Rank) & $\begin{array}{c}-1.004^{\star \star \star} \\
(0.006)\end{array}$ & $\begin{array}{c}-1.177^{\star \star \star} \\
(0.007)\end{array}$ & $\begin{array}{c}-1.177^{\star \star \star} \\
(0.007)\end{array}$ & $\begin{array}{c}-1.109^{\star \star \star} \\
(0.003)\end{array}$ \\
\hline Mobile & & & $\begin{array}{l}-1.522^{\star * *} \\
(0.081)\end{array}$ & $\begin{array}{c}-0.977^{\star \star \star} \\
(0.037)\end{array}$ \\
\hline $\begin{array}{l}\text { Mobile } x \\
\text { In(Sales Rank) }\end{array}$ & & & $\begin{array}{c}0.173^{\star \star *} \\
(0.009)\end{array}$ & $\begin{array}{l}0.109 * \star * \\
(0.004)\end{array}$ \\
\hline Constant & $\begin{array}{c}19.007^{\star \star *} \\
(0.055)\end{array}$ & $\begin{array}{c}20.529 * \star \star \\
(0.060)\end{array}$ & $\begin{array}{c}20.529^{* \star *} \\
(0.060)\end{array}$ & $\begin{array}{c}20.114^{* * *} \\
(0.025)\end{array}$ \\
\hline Adjusted $R^{2}$ & 0.820 & 0.764 & 0.787 & 0.675 \\
\hline Sample size & 21,156 & 25,942 & 47,098 & 47,098 \\
\hline
\end{tabular}

The analysis results show that the sales rank is more strongly associated with the demand in the mobile channel than the PC channel and the difference between the two channels is significant (Table 4), meaning head products made relatively more sales in the mobile channel compared to the PC channel. In the case of revenue, on the other hand, the sales rank is more strongly associated in the PC channel than the mobile channel, and the difference is significant (Table 5). It means that head products relatively generated more revenue in the PC channel than in the mobile channel. Quantile regression analyses show the consistent results (Table 4 and 5).

In sum, demand is more concentrated to popular products in the mobile channel than the PC channel, whereas revenue is the opposite.

\subsection{Comparison of sales distribution by product categories}

Considering the large variance in Gini coefficients reported in previous studies (Table 1), we perform a category-level comparison of the sales distribution between the PC and mobile channels (Table 6). In nine categories, the demand distribution in the mobile channel reports lower Gini coefficients than the PC channel. Specifically, transactions in product categories of high average price (e.g., computer, audio/video supply) and low purchase frequency rate (e.g., health care products) were less concentrated to head products in the mobile channel than the PC channel. When it comes to the revenue distribution, on the other hand, niche products relatively generated more sales in the mobile channel than the PC channel for most product categories.

Table 6. Gini coefficients by product categories

\begin{tabular}{|c|c|c|c|c|c|}
\hline Category & Channel & $\begin{array}{l}\text { Gini Coeff } \\
\text { (demand) }\end{array}$ & $\begin{array}{l}\text { Gini Coeff } \\
\text { (revenue) }\end{array}$ & $\begin{array}{l}\text { Mean Price } \\
(\mathrm{KRW})\end{array}$ & $\begin{array}{l}\text { Order } \\
\text { Frequency }\end{array}$ \\
\hline $\begin{array}{l}\text { Women's } \\
\text { clothing }\end{array}$ & $\begin{array}{l}\mathrm{PC} \\
\text { Mobile }\end{array}$ & $\begin{array}{l}0.39 \\
0.47\end{array}$ & $\begin{array}{l}0.64 \\
0.55\end{array}$ & 19912.93 & 6.19 \\
\hline Computers & $\begin{array}{l}\text { PC } \\
\text { Mobile }\end{array}$ & $\begin{array}{l}0.08 \\
0.06\end{array}$ & $\begin{array}{l}0.73 \\
0.69 \\
\end{array}$ & 318096.93 & 2.27 \\
\hline Computer parts & $\begin{array}{l}\text { PC } \\
\text { Mobile }\end{array}$ & $\begin{array}{l}0.37 \\
0.30\end{array}$ & $\begin{array}{l}0.57 \\
0.55\end{array}$ & 44593.77 & 2.67 \\
\hline $\begin{array}{l}\text { MP3 / PMP / } \\
\text { game }\end{array}$ & $\begin{array}{l}\text { PC } \\
\text { Mobile }\end{array}$ & $\begin{array}{l}0.13 \\
0.22 \\
\end{array}$ & $\begin{array}{l}0.65 \\
0.56 \\
\end{array}$ & 45086.15 & 1.96 \\
\hline $\begin{array}{l}\text { Cell phones \& } \\
\text { accessories }\end{array}$ & $\begin{array}{l}\text { PC } \\
\text { Mobile }\end{array}$ & $\begin{array}{l}0.37 \\
0.37\end{array}$ & $\begin{array}{l}0.59 \\
0.55\end{array}$ & 15082.43 & 2.54 \\
\hline $\begin{array}{l}\text { Kitchen I } \\
\text { household } \\
\text { appliances }\end{array}$ & $\begin{array}{l}\text { PC } \\
\text { Mobile }\end{array}$ & $\begin{array}{l}0.17 \\
0.20\end{array}$ & $\begin{array}{l}0.59 \\
0.58\end{array}$ & 73492.74 & 1.75 \\
\hline $\begin{array}{l}\text { Skincare / } \\
\text { makeup }\end{array}$ & $\begin{array}{l}\text { PC } \\
\text { Mobile }\end{array}$ & $\begin{array}{l}0.41 \\
0.42\end{array}$ & $\begin{array}{l}0.47 \\
0.47\end{array}$ & 20137.87 & 3.86 \\
\hline Men's clothing & $\begin{array}{l}\mathrm{PC} \\
\text { Mobile }\end{array}$ & $\begin{array}{l}0.34 \\
0.44\end{array}$ & $\begin{array}{l}0.46 \\
0.43\end{array}$ & 21491.61 & 3.46 \\
\hline Shoes & $\begin{array}{l}\mathrm{PC} \\
\text { Mobile }\end{array}$ & $\begin{array}{l}0.29 \\
0.35\end{array}$ & $\begin{array}{l}0.41 \\
0.39\end{array}$ & 30425.19 & 2.70 \\
\hline $\begin{array}{l}\text { Sports clothing \& } \\
\text { accessories }\end{array}$ & $\begin{array}{l}\mathrm{PC} \\
\text { Mobile }\end{array}$ & $\begin{array}{l}0.41 \\
0.29\end{array}$ & $\begin{array}{l}0.44 \\
0.41\end{array}$ & 51878.93 & 2.01 \\
\hline Baby goods & $\begin{array}{l}\text { PC } \\
\text { Mobile }\end{array}$ & $\begin{array}{l}0.42 \\
0.51\end{array}$ & $\begin{array}{l}0.57 \\
0.57\end{array}$ & 25347.43 & 8.25 \\
\hline Daily supplies & $\begin{array}{l}\mathrm{PC} \\
\text { Mobile }\end{array}$ & $\begin{array}{l}0.47 \\
0.63\end{array}$ & $\begin{array}{l}0.51 \\
0.48 \\
\end{array}$ & 14130.25 & 3.22 \\
\hline $\begin{array}{l}\text { Automotive } \\
\text { accessories }\end{array}$ & $\begin{array}{l}\text { PC } \\
\text { Mobile }\end{array}$ & $\begin{array}{l}0.37 \\
0.43\end{array}$ & $\begin{array}{l}0.65 \\
0.52\end{array}$ & 25079.34 & 3.19 \\
\hline Furniture / DIY & $\begin{array}{l}\text { PC } \\
\text { Mobile }\end{array}$ & $\begin{array}{l}0.52 \\
0.34\end{array}$ & $\begin{array}{l}0.57 \\
0.50\end{array}$ & 73565.67 & 2.05 \\
\hline $\begin{array}{l}\text { Beverage / snack } \\
\text { / processed food }\end{array}$ & $\begin{array}{l}\mathrm{PC} \\
\text { Mobile }\end{array}$ & $\begin{array}{l}0.47 \\
0.50\end{array}$ & $\begin{array}{l}0.51 \\
0.48\end{array}$ & 15091.40 & 3.72 \\
\hline $\begin{array}{l}\text { Instrument / pet } \\
\text { supplies / flower }\end{array}$ & $\begin{array}{l}\mathrm{PC} \\
\text { Mobile }\end{array}$ & $\begin{array}{l}0.44 \\
0.46 \\
\end{array}$ & $\begin{array}{l}0.69 \\
0.53 \\
\end{array}$ & 31659.58 & 3.05 \\
\hline Books / CDs & $\begin{array}{l}\mathrm{PC} \\
\text { Mobile }\end{array}$ & $\begin{array}{l}0.05 \\
0.07\end{array}$ & $\begin{array}{l}0.41 \\
0.40\end{array}$ & 18178.56 & 1.60 \\
\hline Office stationery & $\begin{array}{l}\text { PC } \\
\text { Mobile }\end{array}$ & $\begin{array}{l}0.63 \\
0.68\end{array}$ & $\begin{array}{l}0.67 \\
0.55\end{array}$ & 11844.82 & 2.06 \\
\hline $\begin{array}{l}\text { Accessories / } \\
\text { jewelry }\end{array}$ & $\begin{array}{l}\mathrm{PC} \\
\text { Mobile }\end{array}$ & $\begin{array}{l}0.41 \\
0.43\end{array}$ & $\begin{array}{l}0.59 \\
0.44 \\
\end{array}$ & 53509.38 & 1.69 \\
\hline Foreign goods & $\begin{array}{l}\text { PC } \\
\text { Mobile }\end{array}$ & $\begin{array}{l}0.11 \\
0.16\end{array}$ & $\begin{array}{l}0.49 \\
0.38\end{array}$ & 103681.16 & 1.94 \\
\hline Birth supplies & $\begin{array}{l}\mathrm{PC} \\
\text { Mobile }\end{array}$ & $\begin{array}{l}0.22 \\
0.33\end{array}$ & $\begin{array}{l}0.52 \\
0.50\end{array}$ & 19168.03 & 4.98 \\
\hline $\begin{array}{l}\text { Plus size /senior } \\
\text { fashion }\end{array}$ & $\begin{array}{l}\text { PC } \\
\text { Mobile }\end{array}$ & $\begin{array}{l}0.20 \\
0.29\end{array}$ & $\begin{array}{l}0.37 \\
0.34\end{array}$ & 19294.06 & 2.93 \\
\hline Bag / wallet & $\begin{array}{l}\mathrm{PC} \\
\text { Mobile }\end{array}$ & $\begin{array}{l}0.45 \\
0.49\end{array}$ & $\begin{array}{l}0.52 \\
0.48\end{array}$ & 21626.87 & 2.54 \\
\hline $\begin{array}{l}\text { Perfume / hair \& } \\
\text { body care }\end{array}$ & $\begin{array}{l}\text { PC } \\
\text { Mobile }\end{array}$ & $\begin{array}{l}0.31 \\
0.37\end{array}$ & $\begin{array}{l}0.47 \\
0.46\end{array}$ & 15257.55 & 3.08 \\
\hline $\begin{array}{l}\text { Outdoors / } \\
\text { climbing / fishing }\end{array}$ & $\begin{array}{l}\text { PC } \\
\text { Mobile }\end{array}$ & $\begin{array}{l}0.35 \\
0.42\end{array}$ & $\begin{array}{l}0.61 \\
0.50\end{array}$ & 43193.35 & 2.16 \\
\hline Golf & $\begin{array}{l}\text { PC } \\
\text { Mobile }\end{array}$ & $\begin{array}{l}0.31 \\
0.34\end{array}$ & $\begin{array}{l}0.61 \\
0.57 \\
\end{array}$ & 83682.41 & 1.89 \\
\hline $\begin{array}{l}\text { Camera \& } \\
\text { accessories }\end{array}$ & $\begin{array}{l}\text { PC } \\
\text { Mobile }\end{array}$ & $\begin{array}{l}0.49 \\
0.81\end{array}$ & $\begin{array}{l}0.82 \\
0.76\end{array}$ & 112463.27 & 2.02 \\
\hline Audio / office & PC & 0.24 & 0.64 & 75397.12 & 1.67 \\
\hline
\end{tabular}




\begin{tabular}{|c|c|c|c|c|c|}
\hline supplies & Mobile & 0.18 & 0.59 & & \\
\hline \multirow{2}{*}{ Kids' clothing } & PC & 0.31 & 0.41 & \multirow{2}{*}{11879.09} & \multirow{2}{*}{3.14} \\
\hline & Mobile & 0.42 & 0.42 & & \\
\hline \multirow{2}{*}{ Toys / education } & PC & 0.19 & 0.53 & \multirow{2}{*}{27037.17} & \multirow{2}{*}{2.29} \\
\hline & Mobile & 0.35 & 0.53 & & \\
\hline \multirow{2}{*}{ Fresh foods } & PC & 0.39 & 0.58 & \multirow{2}{*}{16374.99} & \multirow{2}{*}{3.43} \\
\hline & Mobile & 0.38 & 0.45 & & \\
\hline \multirow{2}{*}{$\begin{array}{l}\text { Bedding / curtain } \\
\text { / carpet }\end{array}$} & PC & 0.44 & 0.49 & \multirow{2}{*}{17758.20} & \multirow{2}{*}{2.01} \\
\hline & Mobile & 0.30 & 0.46 & & \\
\hline \multirow{2}{*}{$\begin{array}{l}\text { Health care I } \\
\text { tools }\end{array}$} & PC & 0.45 & 0.61 & \multirow{2}{*}{38274.44} & \multirow{2}{*}{1.74} \\
\hline & Mobile & 0.23 & 0.52 & & \\
\hline \multirow{2}{*}{$\begin{array}{l}\text { Vehicle } \\
\text { electronics }\end{array}$} & PC & 0.05 & 0.68 & \multirow{2}{*}{62295.65} & \multirow{2}{*}{1.81} \\
\hline & Mobile & 0.22 & 0.63 & & \\
\hline $\begin{array}{l}\text { E-coupon I } \\
\text { voucher }\end{array}$ & $\begin{array}{l}\mathrm{PC} \\
\text { Mobile }\end{array}$ & $\begin{array}{l}0.56 \\
0.52\end{array}$ & $\begin{array}{l}0.80 \\
0.79\end{array}$ & 21466.74 & 3.56 \\
\hline
\end{tabular}

For the better comparison of the Gini coefficients, we locate each product category into the $\mathrm{XY}$ axis graph where $\mathrm{x}(\mathrm{y})$-value is the difference in Gini coefficients of the demand (revenue) distribution between the mobile and PC channels (Figure 3). Most categories locate in Q4, meaning head products relatively generated more sales but less revenue in the mobile channel compared to the PC channel. This suggests users preferred the PC channel to the mobile channel for purchasing expensive products in those categories. Nine categories locate in Q3 in which head products generated both less sales and revenue in the mobile channel than the PC channel, suggesting the mobile channel could promote more searches than the PC channel especially in those categories. Three categories locate in Q1 where head products generated more sales and revenue in the mobile channel.

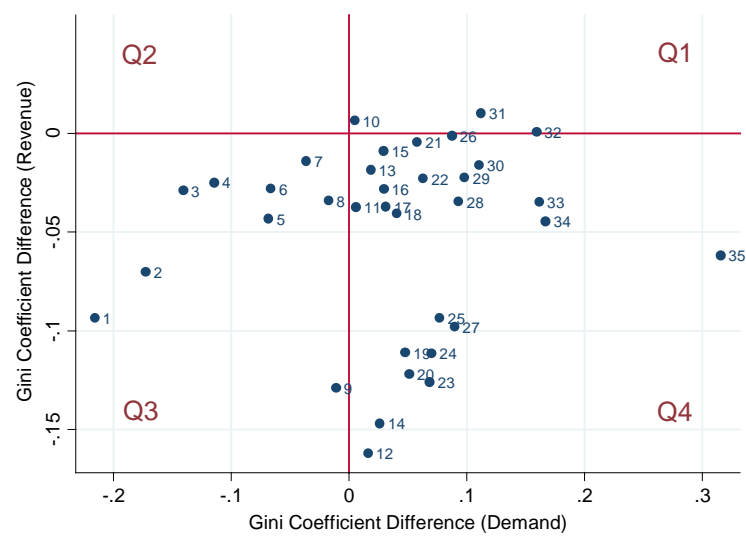

Figure 3. Gini coefficient difference between channels

Note: product category 1: health care/tools, 2: furniture/DIY, 3: bedding/curtain/carpet, 4: sports clothing \& accessories, 5: audio/office supplies, 6: computer parts \& components, 7: e-coupon/voucher, 8: computers, 9: fresh food, 10: skincare/makeup, 11: cell phones \& accessories, 12: instrument/pet supplies/flower 13: books/CDs, 14 accessories/jewelry, 15: kitchen/household appliances, 16 beverage/snack/processed food, 17: golf, 18: bag/wallet/fashion accessories, 19: foreign goods, 20: office stationery, 21: perfume/hair \& body care, 22: shoes, 23: automotive accessories, 24 outdoors/climbing/fishing, 25: women's clothing, 26: baby goods, 27 MP3/PMP/game, 28: plus size/senior fashion, 29: men's clothing, 30: birth supplies, 31: kids' clothing, 32: toys/education, 33: daily supplies, 34: vehicle electronics, 35: camera \& accessories
The contrasting results across product categories and between the demand and revenue distributions naturally lead us to the question of why. We open the discussion and provide the possible explanation about our results in the next section.

\section{Search cost and sales distribution}

The long tail phenomenon in online markets is mainly driven by two forces-the increased product variety on the supply side [6][23][26] and advanced search tools available online on the demand side [4][13]. Unlike brick-and-mortar retailers, online retailers are free from the constraints of product storage and display space, which enable them to provide the increased product variety to the market. Advanced online search tools lower users' search cost to find products that better fit their needs, making niche products viable in the market.

Both PC and mobile channels are electronic channels that are free from physical constraints. Therefore, there is no difference between the two channels on the supply side. When it comes to the demand side, however, the two channels would incur different search cost. The search cost in the PC channel consists of two parts, 1) the transportation cost of finding the place that has the fixed Internet and a PC [2] and 2) the information processing cost of finding and comparing alternatives to make a purchase decision [21]. Small screens and limited usability of mobile devices hamper extensive information processing and incur higher information processing cost. However, the ubiquity of mobile channels allows a better accessibility to online markets and reduces the transportation cost. Considering the both, product search in the mobile channel could incur either higher or lower cost than the PC channel.

Information-intensity of products refers to the amount of information required to make a purchase decision [3]. Searching for information-intensive products would incur much higher cost in the mobile channel than in the PC channel, as it involves higher information processing cost than the PC channel [3]. Consequently, more searches and longer demand distributions are expected in the PC channel than in the mobile channel for information-intensive products. On the other hand, when searching for products with low information-intensity, more searches and longer demand distributions are expected in the mobile channel, as the transportation cost accounts for most search cost incurred.

Both product price and purchase frequency rate could affect the information-intensity of products. Anecdotal evidence shows that consumers spend more 
time and effort for search when purchasing expensive products than inexpensive products. Prior studies also show that product price is the major indicator of involvement [17] and drives more search behaviors [7] [15]. Consumers might have pre-knowledge for the products which they are frequently buying, and would conduct less search for those products [24].

\section{Conclusion}

Despite the proliferation of studies on the sales distribution in e-commerce, little research has been conducted on the sales distribution in the m-commerce channel. Furthermore, since most prior studies focus on the demand curve of a single product category, there is little guidance how the sales distribution in the mobile channel would differ across product categories. This study aims to expand this stream of research by investigating the sales distribution in the mobile channel across multiple product categories.

Overall, transactions in the mobile channel are more concentrated to head products compared to the PC channel sales, but the pattern is inconsistent across product categories. Transactions in product categories of high average price (e.g., computers) and low purchase frequency rate (e.g., health care products) are less concentrated to head products in the mobile channel than the PC channel. From the search cost perspective, we provide explanations why the sales distribution in a certain category has a longer (or shorter) tail in the mobile channel.

In case of the revenue distribution, on the other hand, head products contribute less revenue in the mobile channel than the PC channel. This implies that users tend to purchase expensive products through the PC channel than the mobile channel given the product category.

This study provides several theoretical implications. First, to the best of our knowledge, this is one of the first studies that investigate the sales distribution in the m-commerce channel and compare the sales distribution in the mobile channel with the PC channel across product categories. From the search cost perspective, we explain why the sales distribution of certain product categories is more skewed in the mobile channel than the PC channel. Prior studies presume that the mobile channel has higher search cost than the traditional PC channel due to smaller screen size and limited usability [11][12]. However, our results imply that the search cost can be different depending on product category, and the PC channel has fatter head than the mobile channel in some product categories.

\section{References}

[1] Anderson, C., "The Long Tail", WIRED Magazine, 12(10), 2004, pp. 170-177.

[2] Bakos, J.Y., "Reducing Buyer Search Costs: Implications for Electronic Marketplaces", Management Science, 43(12), 1997, pp. 1676-1692.

[3] Bang, Y., Lee, D.-J., Han, K., Hwang, M., and Ahn, J.-H., "Channel Capabilities, Product Characteristics, and the Impacts of Mobile Channel Introduction", Journal of Management Information Systems, 30(2), 2013, pp. 101-126. [4] Brynjolfsson, E., Hu, Y. (Jeffrey), and Simester, D., "Goodbye Pareto Principle, Hello Long Tail: The Effect of Search Costs on the Concentration of Product Sales", Management Science, 57(8), 2011, pp. 1373-1386.

[5] Brynjolfsson, E., Hu, Y. (Jeffrey), and Smith, M.D., "Consumer Surplus in the Digital Economy: Estimating the Value of Increased Product Variety at Online Booksellers", Management Science, 49(11), 2003, pp. 1580-1596.

[6] Brynjolfsson, E., Hu, Y. (Jeffrey), and Smith, M.D., "The Longer Tail: The Changing Shape of Amazon's Sales Distribution Curve", 2010, pp. 1-13.

[7] Chaudhuri, A., "A Macro Analysis of the Relationship of Product Involvement and Information Search: The Role of Risk", Journal of Marketing Theory and Practice, 8(1), 2000, pp. 1-15.

[8] Chellappa, R., Konsynski, B., Sambamurthy, V., and Shivendu, S., "An empirical study of the myths and facts of digitization in the music industry", Workshop Information Systems Economics (WISE), 2007.

[9] Elberse, A. and Oberholzer-Gee, F., "Superstars and Underdogs: An Examination of the Long-Tail Phenomenon in Video Sales", Working paper in Harvard Business School, 2007.

[10] Fader, P.S., Hardie, B.G.S., and Lee, K.L., "RFM and CLV: Using Iso-Value Curves for Customer Base Analysis", Journal of Marketing Research, 42(4), 2005, pp. 415-430.

[11] Ghose, A., Goldfarb, A., and Han, S.P., "How is the Mobile Internet Different? Search Costs and Local Activities", Information Systems Research, 24(3), 2012, pp. 613-631.

[12] Ghose, A. and Park, S., "The Negative Impact of Mobile Devices on Niche Product Consumption", International Conference on Information Systems (ICIS), 2013.

[13] Hinz, O., Eckert, J., and Skiera, B., "Drivers of the Long Tail Phenomenon: An Empirical Analysis", Journal of Management Information Systems, 27(4), 2011, pp. 43-70. [14] Jung, J., Kim, Y., and Chan-Olmsted, S., "Measuring Usage Concentration of Smartphone Applications: Selective Repertoire in a Marketplace of Choices", Mobile Media \& Communication, 2(3), 2014, pp. 352-368.

[15] Kapferer, J.-N. and Laurent, G., "Consumers' Involvement Profile: New Empirial Restuls", Advances in Consumer Research, 12(1), 1985, pp. 290-295.

[16] Kumar, A., Smith, M.D., and Telang, R., "Information Discovery and the Long Tail of Motion Picture Content", MIS Quarterly, 38(4), 2014, pp. 1057-1078.

[17] Laurent, G. and Kapferer, J.-N., "Measuring Consumer Involvement Profiles", Journal of Marketing Research, 1985, pp. 41-53. 
[18] Oestreicher-Singer, G. and Sundararajan, A.,

"Recommendation Networks and the Long Tail of Electronic Commerce", MIS Quarterly, 36(1), 2012, pp. 65-84.

[19] Oh, H., Animesh, A., and Pinsonneault, A., "Free versus for-a-Fee: The Impact of a Paywall on the Pattern and Effectiveness of Word-of-Mouth via Social Media", MIS Quarterly, 40(1), 2016, pp. 31-56.

[20] Peltier, S. and Moreau, F., "Internet and the 'Long Tail versus Superstar Effect' Debate: Evidence from the French Book Market", Applied Economics Letters, 19(8), 2012, pp. 711-715.

[21] Ratchford, B.T., "Cost-Benefit Models for Explaining Consumer Choice and Information Seeking Behavior", Management Science, 28(2), 1982, pp. 197-212.

[22] Tan, T. and Netessine, S., "Is Tom Cruise Threatened? Using Netflix Prize Data to Examine the Long Tail of

Electronic Commerce", Working paper in Wharton School, University of Pennsylvania, 2009.
[23] Tan, T., Netessine, S., and Hitt, L.M., "Plenty is no Plague, or is it? An Empirical Study of the Impact of Product Variety on Demand Concentration", Working paper in Wharton School, University of Pennsylvania, 2014.

[24] Wang, R.J.-H., Malthouse, E.C., and Krishnamurthi, L., "On the Go: How Mobile Shopping Affects Customer Purchase Behavior", Journal of Retailing, 91(2), 2015, pp. 217-234.

[25] Zhong, N. and Michahelles, F., "Google Play is not a Long Tail Market: An Empirical Analysis of App Adoption on the Google Play App Market", Proceedings of the 28th Annual ACM, 2013, pp. 499-504.

[26] Zhou, W. and Duan, W., "Online User Reviews, Product Variety, and the Long Tail: An Empirical Investigation on Online Software Downloads", Electronic Commerce Research and Applications, 11(3), 2012, pp. 275-289. 